\title{
Ordovician Gastropoda from Northeast Greenland
}

\author{
DAVID M. ROHR, DAVID A.T. HARPER, SVEnd StOUGE \& JøRGEN L. CHRISTIANSEN
}

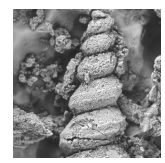

\begin{abstract}
Nine gastropod genera are described from the Ordovician (upper Ibexian portion) of the Narwhale Sound Formation of Hudson Land in Northeast Greenland. The gastropods have Laurentian affinities, and eight of the Greenland genera described here also occur in the Catoche, Aguathuna or Table Point formations of western Newfoundland. Taxa include Maclurites acuminatus (Billings, 1865), Helicotoma sp. indet., operculum and shell of Ceratopea cf. unguis Yochelson \& Bridge, 1957, Lophospira aff. perelegans Stauffer, 1937, Turritoma aff. acrea (Billings, 1865), Hormotoma augustina? Billings, 1865, Straparollina sp., Lophonema taneyensis (Cullison, 1944), and Boucotspira antelopensis (Rohr, 1996). Key words: Ordovician, Narwhale Sound Formation, Greenland, Newfoundland, Hudson Land, gastropod.
\end{abstract}

Rohr, D.M., HARPer, D.A.T., Stouge, S. \& ChristiAnSEN, J.L. 2015. Ordovician Gastropoda from Northeast Greenland. Bulletin of Geosciences 90(4), 795-805 (4 figures). Czech Geological Survey, Prague. ISSN 1214-1119. Manuscript received May 28, 2015; accepted in revised form September 9, 2015; published online November 4, 2015; issued November 30, 2015

David M. Rohr, Department of Biology, Geology and Physical Sciences, Sul Ross State University, Alpine, Texas 79830, U.S.A; drohr@sulross.edu •David A.T. Harper, Department of Earth Sciences, Durham University, Durham DH1 3LE, UK; david.harper@durham.ac.uk•Svend Stouge, Natural History Museum of Denmark, Geological Museum, University of Copenhagen, DK-1350 Copenhagen K, Denmark; svends@snm.ku.dk・Jørgen L. Christiansen, University College Zealand, 4000 Roskilde,Denmark; jlc@ucsj.dk

Ordovician gastropods were described from eastern Greenland on Ella $\varnothing$ by Yochelson (1964) and from northern Greenland by Peel (1980), Fortey \& Peel (1988), Poulsen (1927), Troelsen (1949), and Peel \& Yochelson (1974). Poulsen \& Rasmussen (1951) identified, but did not illustrate or describe Eccyliopterus, Lophospira, Pagodispira and Trochonema from the lower unit of the Narwhale Sound Formation on Ella $\varnothing$ and farther south on the eastern coast of Greenland.

The main purpose of this paper is to systematically describe new material of Ordovician gastropods collected from part of the Narwhale Sound Formation of the Fimbulfjeld Group (Stouge et al. 2013).

\section{Location and regional geology}

The material was collected from the Narwhale Sound Formation at the type section for the Heim Bjerge Formation (e.g. Cowie \& Adams 1957), Albert Heim Bjerge in Hudson Land (Fig. 1; N 74 04' 46.0"; W 230.' 56.4"). The localities (Fig. 1) are in UTM zone 27: AB05 (0436966 mE, $8222212 \mathrm{mN})$, AB07 (0436115 mE, $8222248 \mathrm{mN})$, AB08 (0438105 mE, $8222225 \mathrm{mN})$ and AB09 (0438035 mE, $8222194 \mathrm{mN})$.
The Narwhale Sound Formation was first named by Poulsen (1930) based on the outcrops on Ella Ø, where the formation is incompletely developed. The succession of the Narwhale Sound Formation is completely exposed in the Albert Heim Bjerge region and the formation was redescribed by Cowie \& Adams (1957), under the name Narhvalsund Formation. The 350 to max 600 m thick Narwhale Sound Formation (Fig. 2) of the Fimbulfjeld Group (Kong Oscars Fjord Supergroup) is dominated by carbonates and has been subdivided into three subunits (Stouge $e t$ al. 2013). The lower subunit is about $65 \mathrm{~m}$ thick; it is composed of outer-shelf siliciclastic, mainly argillites and open-marine, grey to dark-brown, parted to ribbon limestone. A six $\mathrm{m}$ thick stromatolite- and chert-bearing horizon divides the lower unit, and it forms a marker horizon, and probably is a response to a brief drop in sea level. The second subunit is $160 \mathrm{~m}$ thick and is composed of interbeds of mainly wackestone-grainstone together with stromatoporoid patch reefs representing a shallow open-shelf depositional environment. The third subunit, $125 \mathrm{~m}$ thick, consists of inner-shelf to tidal-flat dolomitic carbonates composed of stromatolites, laminated dolostones, and massive fine-grained dolostones. Macrofossils are generally sparse in the lower and middle subunits of the formation and of little or no biostratigraphical value; stromatolite 


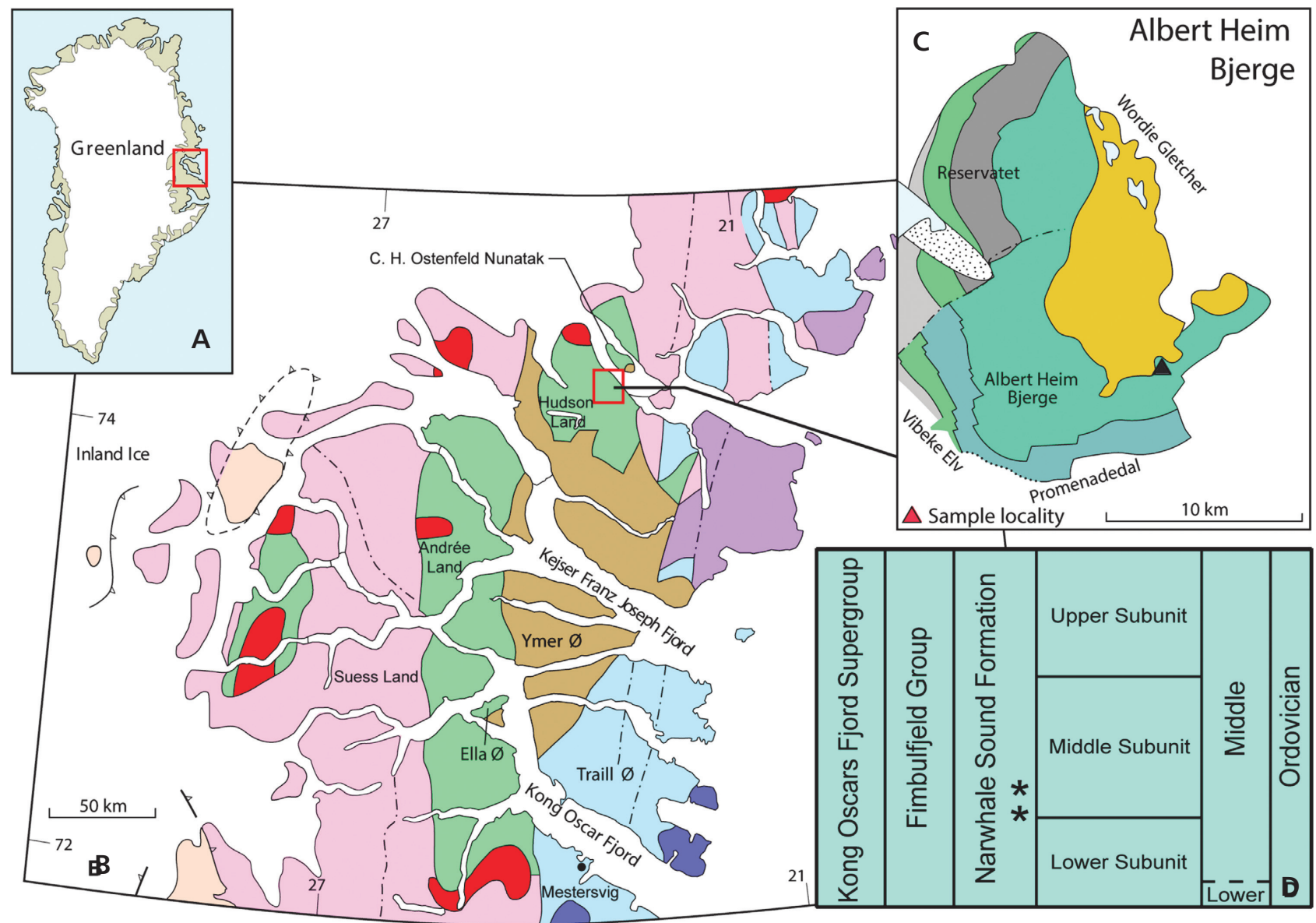

\section{POST-CALEDONIAN}

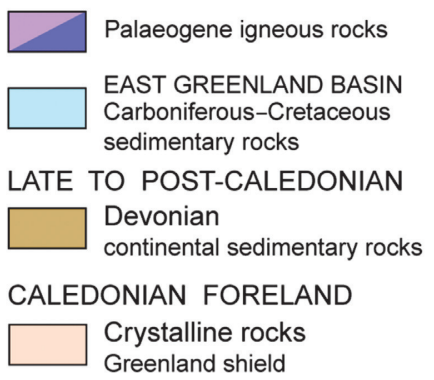

\section{CALEDONIAN OROGENIC BELT}

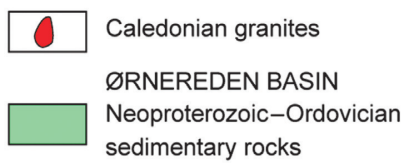

Crystalline complexes Archaean-Mesoproterozoic

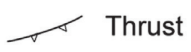

Fault/shear zone

\section{ALBERT HEIM BJERGE}

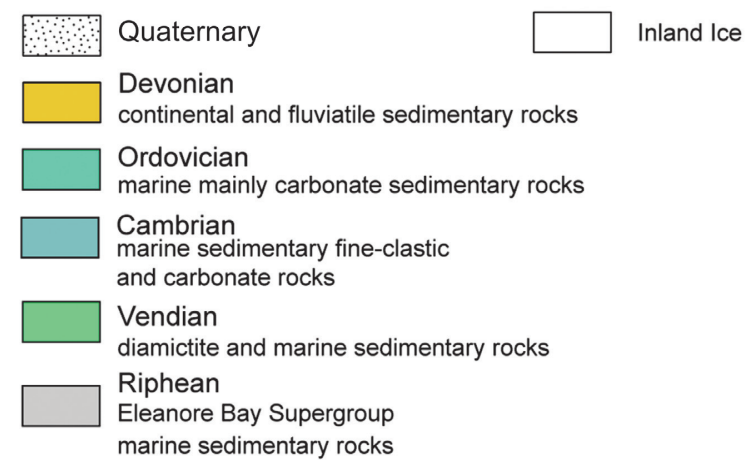

Figure 1. Gastropod locality and horizons in the Narwhale Sound Formation. $\bullet$ A - general location of study area in Northeastern Greenland. $\bullet$ B - geology of Northeast Greenland. $\bullet$ C - geology of Albert Heim Bjerge region, Hudson Land showing gastropod locality. $\bullet$ D - Narwhale Sound Formation and subdivision of the Narwhale Sound Formation proposed by Stouge et al. (2013). * = Stratigraphic position of collected gastropods. Fig. 1A, B is modified from Stouge et al. (2002); Fig. 1C is based on Cowie \& Adams (1957).

beds and oncolites are common in the upper part of the succession. In the lower subunit, the fauna is composed mainly of rare gastropods [Hormotoma sp. and Ceratopea opercula (Yochelson, 1964)]. From the base of the second subunit, a significant faunal change occurs and abundant stromatoporoids and gastropods associated with some solitary corals appear. Lower in the succession, patch reefs and mounds were constructed exclusively by stromatolites and thrombolites.

\section{Material}

The gastropods that form the basis of this study were col- 


\begin{tabular}{|c|c|c|c|c|c|c|}
\hline \multirow{2}{*}{\multicolumn{2}{|c|}{$\begin{array}{l}\text { SYSTEM } \\
\text { SERIES }\end{array}$}} & \multirow{3}{*}{$\begin{array}{c}\text { CONODONT } \\
\text { ZONES/ } \\
\text { SUBZONES } \\
\text { Histiodella } \\
\text { belburnensis }\end{array}$} & \multicolumn{2}{|c|}{$\begin{array}{l}\text { Western } \\
\text { Newfoundland }\end{array}$} & \multicolumn{2}{|c|}{ Northeastern Greenland } \\
\hline & & & Group & Formation & Group & Formation \\
\hline \multirow{6}{*}{$\begin{array}{l}z \\
\frac{1}{0} \\
\frac{0}{2} \\
0 \\
0 \\
0 \\
0\end{array}$} & \multirow{4}{*}{ 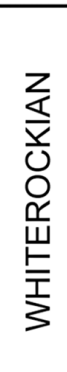 } & & \multirow{3}{*}{$\begin{array}{l}\text { Table } \\
\text { Head }\end{array}$} & \multirow{2}{*}{ Table Cove } & \multirow{3}{*}{$\begin{array}{l}\text { Granata } \\
\text { Glet- } \\
\text { scher }\end{array}$} & \multirow{3}{*}{ Heim Bjerge } \\
\hline & & $\begin{array}{c}\text { Histiodella } \\
\text { kristinae }\end{array}$ & & & & \\
\hline & & $\begin{array}{l}\text { Histiodella } \\
\text { holodentata }\end{array}$ & & Table Point & & \\
\hline & & $\begin{array}{l}\text { (not zoned) } \\
\text { Pteracontiodus } \\
\text { cryptodens }\end{array}$ & \multirow{3}{*}{$\begin{array}{l}\text { St. } \\
\text { George }\end{array}$} & Aguathuna & \multirow{3}{*}{$\begin{array}{l}\text { Upper } \\
\text { Fimbul- } \\
\text { fjeld }\end{array}$} & $\begin{array}{l}\text { Narwhale } \\
\text { Sound }\end{array}$ \\
\hline & \multirow{2}{*}{ 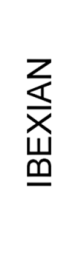 } & $\begin{array}{c}\text { Protoprioniodus } \\
\text { simplicissimus- } \\
\text { Oepikodus communis }\end{array}$ & & Catoche & & Cape Weber \\
\hline & & $\begin{array}{c}\text { Acodus delicatus- } \\
\text { A.? primus }\end{array}$ & & Boat Harbour & & Septembersø \\
\hline
\end{tabular}

Figure 2. Stratigraphy and correlation of Western Newfoundland and Northeastern Greenland. Conodont zones of Ji \& Barnes (1994).

lected by D.A.T. Harper, S. Stouge and J.L. Christiansen in 2008 from the Narwhale Sound Formation exposed in Hudson Land, Northeast Greenland (Fig. 1). The specimens were collected from two beds at the top of the lower subunit and the base of the middle subunit of Stouge et al. (2013). The specimens are heavily silicified, and they were handpicked individually from weathered limestone surfaces and later acidized from the matrix. Secondary concentric silicification structures (beekite rings) are abundant on some specimens and obscure the ornamentation.

\section{Age of fauna}

Ordovician gastropods are generally of limited value for biostratigraphy; however, the presence of Ceratopea billingsi (not found during this study but reported by Yochelson 1964) suggests an uppermost Lower Ordovician assignment for the lower part of the Narwhale Sound Formation. Also found in these four localities in the Narwhale Sound, Ceratopea unguis is a younger species of Ceratopea (Yochelson \& Wise, 1957), but it is also latest Ibexian. According to Stouge et al. (2013), the Lower-Middle Ordovician boundary is probably conformable in the area and occurs within the lower part of the Narwhale Sound Formation.

The associated conodont fauna and faunal succession of the Narwhale Sound Formation is typical Laurentian. In the lower fine-grained clastic subunit, an assemblage first composed of Tripodus cf. laevis, is followed by Pteracontiodus cryptodens and Histiodella altifrons; the higher subunits of the formation have yielded a diagnostic fauna composed of Middle Ordovician hyaline conodonts of Midcontinent affinity, and the upper unit includes Discidognathus primus and Multioistodus subdentatus. These biostratigraphic data suggest that the formation extends from the upper Ibexian (Smith 1991) to middle Whiterockian (Smith 1991, Stouge et al. 2013).

\section{Comparison to the Ordovician of Newfoundland}

Lower and Middle Ordovician shallow-water platform carbonate rocks are widely exposed in western Newfoundland, and they were connected to a carbonate platform succession that extended to eastern Greenland, northern Scotland and Svalbard (Poulsen 1951, Swett \& Smit 1972, Stouge et al. 2013). The Barbace Cove Member of the Boat Harbour Formation, the Catoche and Aguathuna formations of the St. George Group form an unconformitybounded, upper Ibexian to lower Whiterockian sequence. The Table Point Formation (Whiterockian) is the lower formation in the Table Head Group and unconformably overlies the St. George Group (Fig. 2). The Aguathuna Formation, the top formation of the St. George Group, is within the Pteracondiotus cryptodens conodont Zone (Ji \& 
Barnes 2004), whereas the lower part of the Table Point Formation is referred to the Histiodella holodentata conodont zone (Stouge 1984, 2012). Gastropods are abundant and diverse (see Billings 1865; Rohr et al. 2000, 2001, 2002) and occur in most beds of all the Ordovician formations in western Newfoundland.

Eight of the nine Greenland genera described here also occur in Catoche, Aguathuna or Table Point formations. Six are assigned to the same species: Maclurites acuminatus (Billings, 1865), Lophonema taneyensis (Cullison, 1944), operculum and shell of Ceratopea unguis Yochelson \& Bridge, 1957, Lophospira aff. perelegans Stauffer, 1937, Turritoma aff. acrea (Billings, 1865), and Hormotoma augustina? Billings, 1865.

Most of the genera are also found in the rest of eastern North America. Boucotspira, Lophonema, Turritoma and Ceratopea provide a unique eastern North America biogeographic signal (Ebbestad et al. 2013).

Repository. - Gastropods in this report are deposited in the Geological Museum (a part of the Natural History Museum of Denmark), University of Copenhagen (MGUH).

\section{Systematic palaeontology}

Family Macluritidae Carpenter, 1861

\section{Genus Maclurites Lesueur, 1818}

Type species. - Maclurites magnus Lesueur, 1818, U.S.A.; Tennessee, Middle Ordovician, Chazyan.

\section{Maclurites acuminatus (Billings, 1865)}

Figure 3A-C

1865 Maclurea acuminata; Billings, p. 240, fig. 215.

1890 Maclurea acuminata Billings. - Whitfield, p. 32, pl. 3, figs 1,2 .

1910 Maclurea acuminata Billings. - Seely, pl. 57, figs 9, 10.

1957 Maclurites florentinensis; Banks \& Johnson, p. 635, pl. 74, figs 4, 5, 10.

1961 Maclurites acuminatus (Billings, 1865). - Yu, p. 34, pl. 1, figs $1,2$.
2001 Maclurites? acuminatus (Billings, 1865). - Rohr \& Measures, p. 268, figs 5.19-5.21.

Material. - Two fragmentary silicified specimens from locality AB08. Illustrated specimen MGUH 31246.

Description. - Small, incomplete specimens $1.5 \mathrm{~cm}$ in diameter, planar base, convex upper surface with narrow, steep-sided umbilicus, which slightly exposes previous whorls. Outer edge of whorl acute, about $45^{\circ}$. Width of whorl on base about doubles per volution.

Remarks. - The species is distinguished by its base, its narrow umbilicus, and absence of previous whorls exposed within the umbilicus. The Greenland species is also similar to Maclurites sp. 1 of Rohr et al. (2001) from the Catoche Formation, which has a narrow umbilicus but a taller shell.

Occurrence. - Cosmopolitan. Blackhillsian of Vermont (Whitfield 1890), Whiterockian Table Point Formation of Newfoundland (Rohr \& Measures 2001), Darriwilian of Tasmania (Banks \& Johnson 1957), upper Lower or lower Middle Ordovician (Arenig) of China (Yu 1961).

Family Helicotomidae Wenz, 1938

Genus Lophonema Ulrich in Purdue \& Miser, 1916

Type species. - Lophonema peccatonica Ulrich in Purdue \& Miser, 1916; U.S.A., Missouri, Blackhillsian.

Lophonema taneyensis (Cullison, 1944)

Figure 4G-I

1944 Polhemia taneyensis; Cullison, p. 55, pl. 26, figs 6-10.

2002 Polhemia taneyensis Cullison, 1944. - Rohr et al., p. 272, figs 6.1-6.12.

Material. - A single specimen from locality AB08. Illustrated specimen MGUH 31261.

Description. - Small, $7 \mathrm{~mm}$ in diameter, low-spired, gradate, phaneromphalous gastropod, sub-hexagonal cross

Figure 3. A-C-Maclurites accuminatus (Billings, 1865); top, apertural and basal views, MGUH 31246, $\times 3$, loc. AB08. • D-F - Helicotoma sp. indet., top, basal, and oblique apertural views, MGUH 31247, ×3, loc. AB09. • G-H, O, P - Ceratopea cf. C. unguis Yochelson \& Bridge, 1957; G-H - side and top views of a fragmentary specimen, MGUH 31248, loc. AB07; O, P - top and abapertural view, MGUH 31249, × 3, loc. AB04. • I-N - operculum of Ceratopea unguis Yochelson \& Bridge, 1957; I-K - apertural and side views, MGUH 31250, × 2, loc. AB08; L-N - apertural and side views, MGUH 31251, × 3, loc. AB07. • Q-S - Lophospira aff. L. perelegans Stauffer, 1937; side views, MGUH 31252, × 3, loc. AB08; MGUH 31253, × 3, loc. AB09; MGUH 31254, × 3, loc. AB08. • T - Turritoma aff. acrea (Billings, 1865); side view, MGUH 31255, × 3, loc. AB08. • U - Hormotoma augustina? Billings, 1865; side view, MGUH 31256, × 3, loc. AB09. 

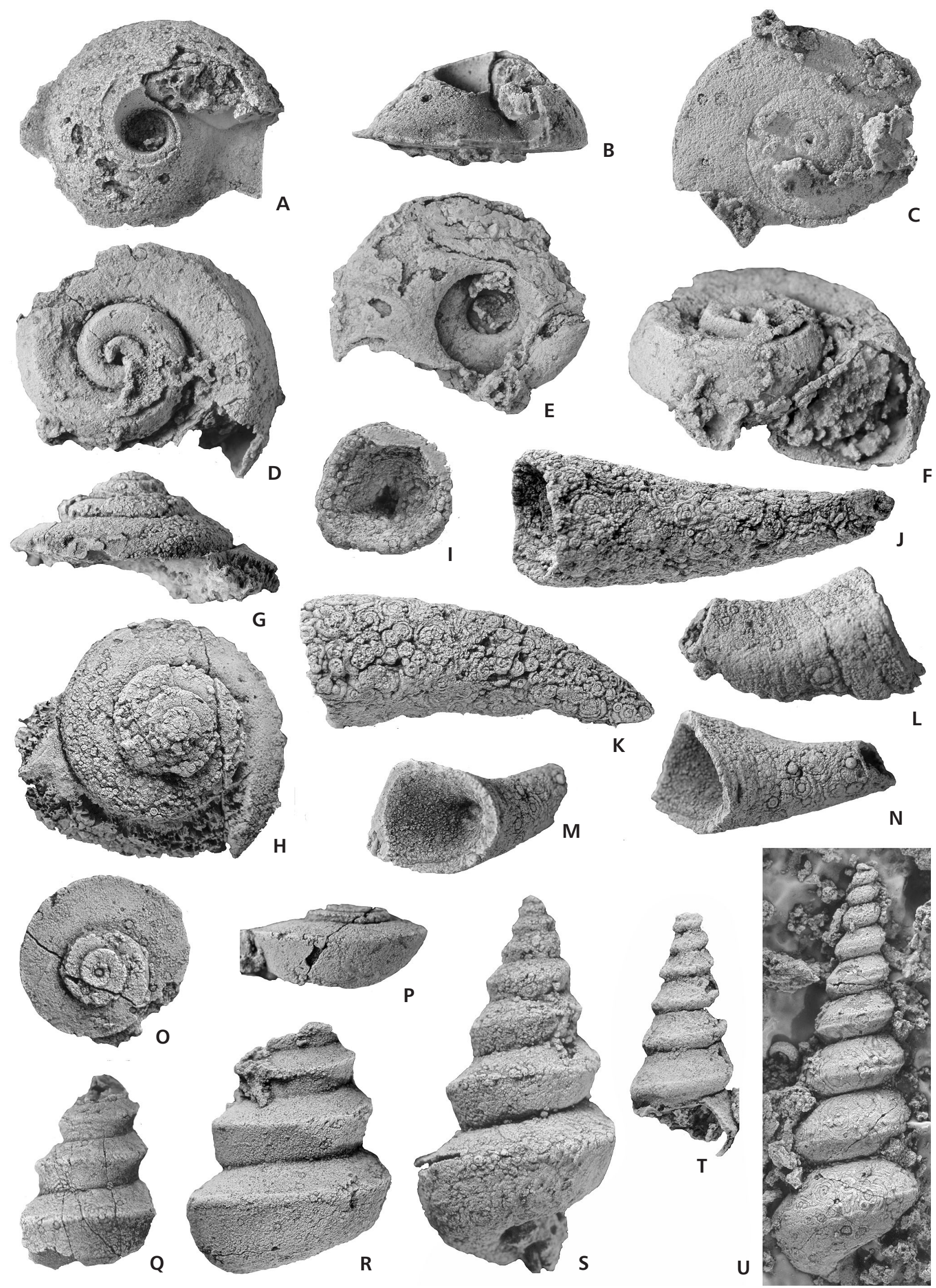
section, with three angulations present: at whorl shoulder, at midwhorl and around base of whorl.

Remarks. - The shape of the specimen appears to be nearly identical to, L. taneyensis. Lophonema frydai (Rohr, 1996) is higher spired. The small Greenland specimen does not display any the spiral cords of $L$. taneyensis. The poorly known Lophonema peccatonia Ulrich in Purdue \& Miser, 1916, appears to be more rounded.

Occurrence. - Lophonema taneyensis is a distinctive and relatively abundant gastropod known from the Lower Ordovician (Blackhillisan) Cotter Formation of Missouri (Cullison 1944), and throughout the Blackhillsian portion of the Catoche Formation in Newfoundland (Rohr et al. 2002). A similar species, L. frydai (Rohr, 1994) occurs in the Whiterockian Antelope Valley Formation of Nevada.

Family Helicotomidae Wenz, 1938

\section{Genus Helicotoma Salter, 1859}

Type species. - Helicotoma planulata Salter, 1859; Canada, Quebec, Upper Ordovician, Blackriverian.

\section{Helicotoma sp. indet.}

Figure 3D-F

Material. - Three silicified specimens from locality AB09. Illustrated specimen MGUH 31247.

Description. - Moderately small (up to $18 \mathrm{~mm}$ in diameter) discoidally coiled dextral gastropods having a circular to laterally compressed oval cross section with an angulation at the shoulder. Loosely coiled, deep sutures, flat spire and broad umbilicus exposing about half of the previous whorl; no ornament present.

Remarks. - The shell is low-spired and similar in profile to Helicotoma sp. from the Whiterockian of Nevada (Rohr 1996, fig. 5.8). The type species, $H$. planulata, is higher-spired. Poulsen (1937, pl. 4, figs 7-10) illustrated four poorly preserved, low-spired specimens from the Cape Weber Formation that appear similar to these specimens, although the illustration by Sardeson (1903, fig. 18) shows it to be a very discoidal shell. Billings (1865) named three species from western Newfoundland, but all are poorly preserved.

Occurrence. - Helicotoma is a common (at least 22 named species) and widespread gastropod of the Middle and Upper Ordovician.
Family Euomphalidae de Koninck, 1881

\section{Genus Boucotspira Rohr, 1980}

Type species. - Boucotspira fimbriata Rohr, 1980; U.S.A., California, Ordovician, Whiterockian?.

\section{Boucotspira antelopensis Rohr, 1996}

Figure 4J-L

\author{
1996 Trochonemella antelopensis; Rohr, p. 59, \\ fig. 3.14-3.17. \\ 2002 Boucotspira aff. fimbriata. - Wagner, p. 77, fig. 15.
}

Material. - One fragmentary silicified specimen from locality AB08. Illustrated specimen MGUH 31262.

Description. - Small, single incomplete specimen $1.4 \mathrm{~cm}$ in diameter, apical angle $120^{\circ}$, two strong angulations, one high on whorl and other at periphery. Upper suture shallow, whorl convex to upper angulation; midwhorl broadly convex, sloping at an angle of about $65^{\circ}$ to lower angulation, curving convexly into base. Base not preserved, nature of umbilicus unknown. Growth lines not observed.

Remarks. - The shell profile is similar to Euomphalopterus Roemer, 1876, but lacks the large peripheral frill. Wagner (2002) included Ordovician shells with this shape as "euomphalopterines". Boucotspira has a sinus at the upper angulation, but growth lines are not present on this specimen.

Occurrence. - Whiterockian of northern California (Rohr 1980), Nevada (Rohr 1996) and Greenland.

Family Raphistomatidae Koken, 1896

\section{Genus Ceratopea Ulrich, 1911}

Type species. - Ceratopea keithi Ulrich, 1911; U.S.A., Virginia, Ordovician, Ibexian.

Remarks. - Ceratopea is one of only a few gastropod genera established on the calcareous operculum and not the shell. The operculum is commonly found disassociated, and for many years the nature of the shell itself was unknown (Yochelson 1975). Yochelson \& Bridge (1957, pl. 38, figs 8, 9) illustrated an artificial association of C. unguis with its presumed shell made years earlier by E.O. Ulrich \& J. Bridge (E.L. Yochelson, written comm. 2003). Rohr et al. (2004b) illustrated the first life association of the operculum with a complete shell of C. unguis. 

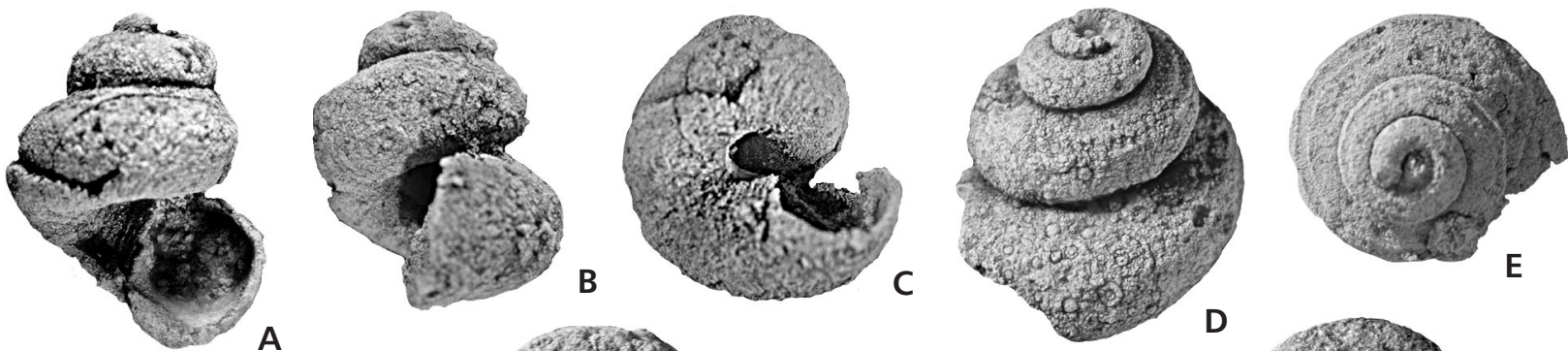

A
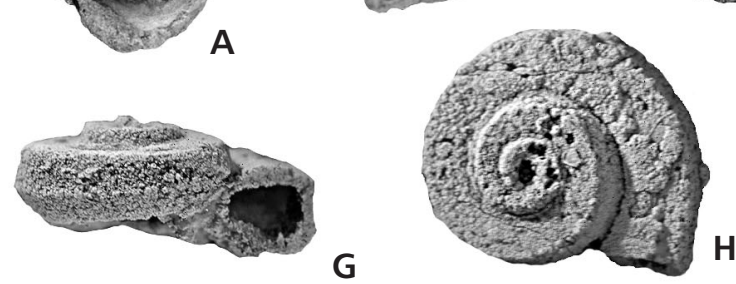

G

$\mathrm{H}$
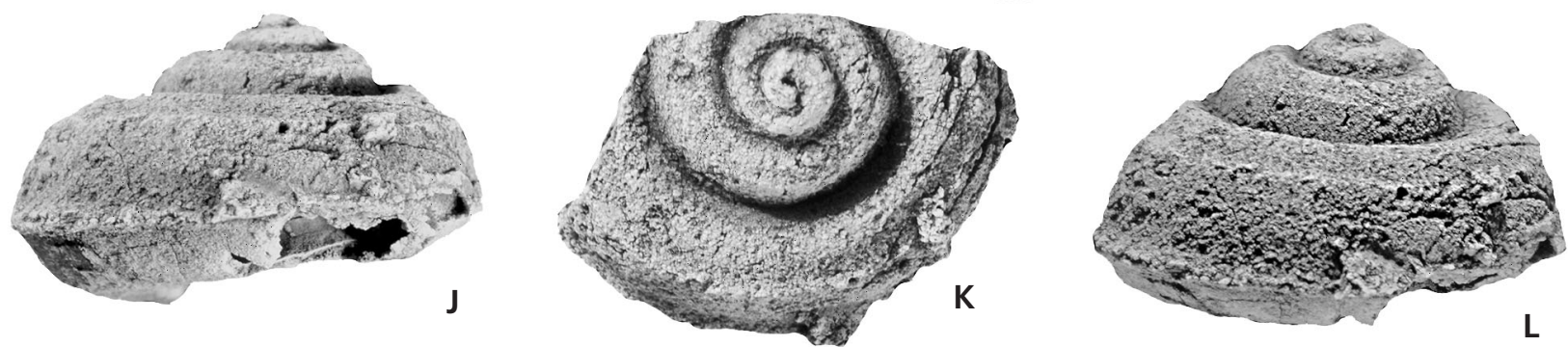

Figure 4. A-F - Straparollina sp.; A-C - apertural, side and basal views, MGUH 31257, ×3, loc. AB08; D - side view with bilineate peripheral band, MGUH 31258, × 3, loc. AB09; E - top view with peripheral band, MGUH 31259, loc. AB07; F - umbilical view, MGUH 31260, × 3, loc. AB04. - G-I - Polhemia taneyensis Cullison, 1944; apertural, top and umbilical views, MGUH 31261, × 3, loc. AB08. $\bullet$ J-L - Boucotspira antelopensis (Rohr, 1996); side views, MGUH 31262, × 3, loc. AB08.

\section{Shell of Ceratopea cf. C. unguis Yochelson \& Bridge, 1957}

Figure 3G-H, O, P

1957 Ceratopea unguis; Yochelson \& Bridge, pp. 300-301, pl. 38 , figs 8,9 .

1972 Ceratopea unguis. - Yochelson \& Wise, p. 681, fig. 1a-c.

2004b Ceratopea unguis. - Rohr, Fix \& Darrough, p. 218, fig. 1.

Material. - One specimen from locality AB07 and one from AB08. Illustrated specimens MGUH 31248 and 31249 .

Description of shell. - Lenticular with bulk of whorl below periphery, dextral shell up to $2.5 \mathrm{~cm}$ in diameter, apical angle 110 to $130^{\circ}$; upper suture incised, slightly gradate, upper whorl surface broadly convex, sharp periphery, convex base; umbilicus present but not well preserved.

Remarks. - The Greenland shells have a shape very similar to Ceratopea unguis. Since the Greenland shells do not preserve the base of the shell well, it is not known if the circum-umbilical cord of $C$. unguis is present. Several spe- cies of Ceratopea occur in western Newfoundland (Rohr $e t$ al. 2000, 2001). Ceratopea normani (Billings, 1865), which is a synonym of $C$. canadensis Yochelson \& Copeland (1974), is known from an internal mold from Billing's (1865) Unit G (Catoche Formation). Shells probably of C. canadensis occur in the Catoche Formation (Rohr et al. 2000, 2001).

Other shells (not opercula) assigned to the genus include Ceratopea buttsi Yochelson \& Bridge, 1957, and C. hami Yochelson \& Bridge, 1957. Ceratopea canadensis (Billings, 1865) from the Oxford Formation (Cassinian) of Ontario, was illustrated by a line drawing (Billings 1865, fig. 328). This species was re-described by Yochelson \& Copeland (1974, p. 205), and they noted, "...no close correspondence between the syntypes and the line drawings." Yochelson \& Copeland (1974) noted the similarity of $C$. unguis and C. canadensis and suggested that they might be placed in synonymy, although they did not. No operculum has been associated with C. canadensis. Wagner (2002) included C. hami (Stauffer, 1937), C. laurentia (Billings, 1865), and C. pygmaea (Stauffer, 1937), and none of these shells have a spiral cord on the base.

Occurrence. - See below. 


\section{Operculum of Ceratopea unguis Yochelson \& Bridge, 1957}

Figure 3I-N

1957 Ceratopea unguis; Yochelson \& Bridge, pp. 300-301, pl. 37, figs 11-14, 19-24, 28; pl. 38, fig. 8 .

1972 Ceratopea unguis. - Yochelson \& Wise, p. 681, fig. 1a-c.

1972 Ceratopea unguis. - Yochelson \& Barnett, pp. 685, fig. 1a-j.

1975 Ceratopea unguis. - Yochelson \& Peel, pp. 230-231, fig. $7 \mathrm{~d}$, e.

1979 Ceratopea unguis. - Peel \& Yochelson, pp. 88-91, fig. $\mathrm{a}-\mathrm{j}$.

1995 Certaopea unguis. - Rohr, Norford \& Yochelson, p. 1052, figs 4.1-4.4.

2004 Ceratopea unguis. - Rohr, Fix \& Darrough, p. 218, fig. 1.

Material. - Twenty-two specimens from locality AB05, seven from $\mathrm{AB} 07$, and four from $\mathrm{AB} 08$, and one from AB09. Illustrated specimens MGUH 31250 and 31251.

Description. - Curved, horn-shaped operculum with a pit at the apertural end; vertically compressed with cross section reflecting shape of aperture of shell; growth lines mostly regular and normal to the axis of the operculum.

Remarks. - Ceratopea unguis is the youngest and most common species of the genus and its operculum expresses the greatest variability (Yochelson \& Bridge 1957). The species can be distinguished from C. buttsi Yochelson \& Bridge, 1957, by its lack of a sharp carina. The growth lines on the operculum do not necessarily reflect the reentrants along the shell aperture, since the operculum was withdrawn inside the aperture (Yochelson \& Bridge 1957, Rohr et al. 2004b). Yochelson \& Copeland (1974) suggested that C. canadensis may be a synonym of C. unguis, but no operculum is associated with it.

Occurrence. - Ceratopea unguis is restricted to the upper Ibexian of eastern Laurentia. Opercula of C. unguis occur in the Nigerbreen Limestone at Spitsbergen (Birkenmajer \& Yochelson 1998), Nunatami and Wandel Valley formations of North Greenland (Peel \& Yochelson 1979), the Aguathuna Formation of western Newfoundland (Yochelson 1992, Rohr et al. 2000), the Providence Island Dolomite (Didymograptus protobifidus Zone) of New York (Yochelson \& Barnett 1972), the Smithville Formation of Arkansas (Yochelson \& Wise 1972, Rohr et al. 2004b), the upper part of the West Spring Creek Formation (Yochelson 1973 ) in Oklahoma, the Rockdale Run Formation of Virginia (Butts 1941) and Maryland (Sando 1957), and the Skoki Formation of British Columbia (Rohr et al. 1995).
Yochelson (1964) illustrated the operculum of Ceratopea billingsi Yochelson, 1964, from the lowest unit of the Narwhale Sound Formation on Ella $\varnothing$, as well as fragmentary specimens that were not assigned to species. The operculum of $C$. billingsi is easily distinguished by its greater degree of curvature in the early stages of growth. Ceratopea billingsi also occurs in the the Wandel Valley Formation in Kronprins Christian Land, eastern North Greenland (Peel 1980), the Durness Limestone, Scotland (Yochelson 1964) and the lower part of the Catoche Formation in Newfoundland (Rohr et al. 2001).

Family Lophospiridae Wenz, 1938

\section{Genus Lophospira Whitfield, 1886}

Type species. - Murchisonia bicincta Hall, 1847; U.S.A., New York, Middle Ordovician, Chatfieldian.

Lophospira aff. L. perelegans Stauffer, 1937

Figure 3Q-S

1937 Lophospira perelegans; Stauffer, p. 57, pl. 10, figs 5, $8,14,15$.

Material. - Eight specimens from locality AB07, five from AB08, and five from AB09. Illustrated specimens MGUH 31252-31254.

Description. - High-spired, apical angle $35-40^{\circ}$, anomphalous with peripheral angulation slightly above mid-whorl; whorl convex above and below angulation; no ornament preserved.

Remarks. - Lophospira is a common and widespread Ordovician genus with many synonyms (Tofel \& Bretsky 1987). The Greenland species differs from L. perangulata, which is concave between angulations and has a sharp lower angulation. Lophospira perelegans, from the Cassinian of Minnesota has a similar profile with a rounded base, but has an apical angle about $65^{\circ}$. Lophospira elegans (Billings, 1865) and L. sorocula (Billings, 1865) are more similar to L. perangulata and are common in the Table Point Formation (Whiterockian) of Newfoundland. Because the ornament and growth lines are not preserved, a more precise assignment is not possible.

Family Hormotomidae Wenz, 1938

\section{Genus Hormotoma Salter, 1859}

Type species. - Murchisonia gracilis Hall, 1847 (p. 181); U.S.A., New York, Middle Ordovician, Chatfieldian. 


\section{Hormotoma augustina? Billings, 1865}

Figure 3U

1865 Murchisonia augustina; Billings, p. 234, fig. 221.

1897 Lophospira augustina? (Billings, 1865). - Ulrich \& Schofield, p. 987, pl. 71, figs 1, 2.

2004 Hormotoma augustina (Billings, 1865). - Rohr, Measures \& Boyce, p. 232, pl. 2, figs 26-28.

Material. - Two specimens from locality AB09. Illustrated specimens MGUH 31256.

Description. - High-spired, apical angle about $20^{\circ}$, up to $3 \mathrm{~cm}$ tall with rounded whorls and impressed suture; band at midwhorl bounded by two spiral cords; no other ornament present.

Remarks. - Hormotoma is a common, high-spired genus in the Table Point Formation of Newfoundland. The shell has the same profile as $H$. augustina, but does not preserve any growth lines and is much smaller that the specimen illustrated by Billings (1865). This species was included by Wagner (2002) in his genus Eroicaspira, but it is retained here in Hormotoma because it does not preserve the characteristic aperture of Eroicaspira.

Family Eotomariidae Wenz, 1938

\section{Genus Turritoma Ulrich \& Scofield, 1897}

Type species. - Murchisonia acrea Billings 1865; Canada, Newfoundland, Lower Ordovician, Blackhillsian.

\section{Turritoma aff. acrea (Billings, 1865)}

Figure 3T

aff. 1865 Murchisonia acrea; Billings, p. 231, fig. 216.

1975 Murchisonia (Turritoma) cf. acrea Billings, 1865. Fix, pl. 3, fig. 1.

Material. - Three silicified specimens from localities AB08. Illustrated specimen MGUH 31255.

Description. - Small, high-spired, apical angle about $25^{\circ}$, upper whorl nearly planar from suture down to subangular periphery; periphery projects slightly over the next whorl.

Remarks. - None of the known specimens preserve any ornamentation.

Occurrence. - Narwhale Sound Formation, Greenland. Billings (1865) described Turritoma acrea from the Catoche Formation (his unit G) at Port au Choix, Newfound- land. Rohr et al. (2001) reported the species from $2 \mathrm{~m}$ above the base of the Catoche Formation. Fix (1975) illustrated the species from the Smithville Formation of Missouri.

Family Straparollinidae Wagner, 2002

\section{Genus Straparollina Billings, 1865}

Type species. - Straparollina pelagica Billings, 1865; Canada, western Newfoundland, Catoche, and Aguathuna formations, Ordovician, Blackhillian-Whiterockian.

\section{Straparollina sp. indet.}

Figure 4A-F

Material. - Thirty specimens from AB07, 45 from locality $\mathrm{AB} 08$, and 30 from AB09. Illustrated specimens MGUH 31257-31260.

Description. - Small, rounded turbinate, apical angle about $50^{\circ}$, narrow umbilicus, with some specimens becoming uncoiled in later whorls. Bilineate peripheral band above midwhorl, sinus and other ornament unknown.

Remarks. - Straparollina is one of the most common specimens in the Greenland material. The shell is like Sinuopea Ulrich, 1911 [for example, P. (?) floweri Fortey \& Peel, 1990, from the Poulsen Cliff Formation, North Greenland] but that genus lacks a peripheral band. Straparollina pelagica from the Whiterockian of Newfoundland, has a circum-umbilical funicle but lacks a peripheral band. Since many features of the shell are not preserved, it is not assigned to a species.

Occurrence. - Late Ibexian-Whiterockian of Newfoundland, Nevada and Greenland.

\section{Acknowledgments}

Fieldwork in Greenland was supported by the Danish Natural Science Research Council and the Carlsberg Foundation. We thank Jan Ove Ebbestad and John Peel for their helpful reviews of the manuscript.

\section{References}

BanKs, M.R. \& Johnson, J.H. 1957. Maclurites and Girvanella in the Gordon River limestone (Ordovician) of Tasmania. Journal of Paleontology 31(3), 632-640.

Billings, E. 1865. Palaeozoic Fossils, Vol. 1. 426 pp. Geological Survey of Canada, Dawson Bros., Montreal. 
Birkenmajer, K. \& Yochelson, E.L. 1998. Ceratopea (Gastropoda) from Lower Ordovician of south Spitsbergen. Bulletin of the Polish Academy of Sciences, Earth Sciences 46(3-4), 157-165.

ButTs, C. 1941. Geology of the Appalachian Valley in Virginia, part 2, fossil plates and explanations. Virginia Geological Survey, Bulletin 52, 1-271.

CARPENTER, P.P. 1861. Lectures on Mollusca; or "shell-fish" and their allies. Annual Report of the Board of Regents of the Smithsonian Institution 1860, 151-283.

Cowie, J.W. \& AdAms, P.J. 1957. The geology of the Cambro-Ordovician rocks of central East Greenland. Meddelelser om Grønland 153(1), 1-193.

Cullison, J.S. 1944. The stratigraphy of some Lower Ordovician formations of the Ozark uplift. University of Missouri School of Mines and Metallurgy Technical Series Bulletin 15(2), $1-112$.

Ebbestad, J., Frýda, J., Wagner, P., Horný, R., Isakar, M., Stewart, S., Percival, I., Bertero, V., Rohr, D., Peel, J., Blodgett, R. \& Hogstrom, A. 2013. Chapter 15; Biogeography of Ordovician and Silurian gastropods, monoplacophorans and mimospirids. Memoirs of the Geological Society of London 38, 199-220.

FIX, M.F. 1975. The paleontology and stratigraphy of the Smithville and Blackrock formations of Southeastern Missouri. 147 pp. M.S. thesis, Geology, Washington University.

Fortey, R.A. \& Peel, J.S. 1990. Early Ordovician trilobites and molluscs from the Poulsen Cliff Formation, Washington Land, western North Greenland. Bulletin of the Geological Society of Denmark 38(1-2), 11-32.

HaLL, J. 1847. Containing descriptions of the organic remains of the lower division of the New York system (equivalent of the Lower Silurian rocks of Europe). Paleontology of New York 1, $1-338$.

Ji, Z. \& BARNES, C.R. 1994. Lower Ordovician conodonts of the St. George Group, Port au Port Peninsula, western Newfoundland, Canada. Palaeontographica Canadiana 11, 1-149.

KoKen, E. 1896. Die Leitfossilien. 848 pp. Tauchnitz, Leipzig.

Koninck, L.G. DE 1881. Faune du calcaire carbonifère de la Belgique, série paléontologique Pt. 3, Gastéropodes. Annales du Musée royal d'Histoire naturelle de Belgique, series 6, $1-170$.

LESUEUR, C.A. 1818. Observations on a new genus of fossil shells. Journal of the Academy of Natural Sciences of Philadelphia 1, 310-313.

PeEl, J. 1980. Ceratopea billingsi (Gastropoda) from the Early Ordovician of Kronprins Christian Land, eastern North Greenland. Rapport Grønlands Geologiske Undersøgelse 101,68 .

Peel, J.S. \& Yochelson, E.L. 1979. Ceratopea (Gastropoda) from Washington Land, western North Greenland. Rapport Grønlands Geologiske Undersøgelse 91, 87-91.

Poulsen, C. 1930. Contributions to the stratigraphy of the Cambro-Ordovician of East Greenland. Meddelelser om Grønland 74(12), 299-316.

Poulsen, C. 1937. On the Lower Ordovician faunas of east Greenland. Meddelelser om Grønland 119(3), 1-72.

Poulsen, C. 1951. The position of the East Greenland
Cambro-Ordovician in the Palaeogeography of the North-Atlantic Region. Meddelelser fra Dansk Geologisk Forening 12, $161-162$.

Poulsen, C. \& Rasmussen, H.W. 1951. Geological map (scale 1:50,000) and description of Ella Ø. Meddelelser om Grønland 47(3), 1-25.

Purdue, A.H. \& Miser, H.D. 1916. Eureka Springs-Harrison folio, Arkansas-Missouri. Geological Atlas of the United States, Folio GF-202. 22 pp. United States Geological Survey.

Roemer, C.F. 1876. Beiträge zur geologischen Kenntniss des nordwestlichen Harzgebirges. Palaeontographica 5, 1-44.

RoHR, D.M. 1980. Ordovician-Devonian Gastropoda from the Klamath Mountains, California. Palaeontographica, Abteilung A-Palaeozoologie-Stratigraphie 171(4-6), 141-210.

RoHR, D.M. 1996. Ordovician (Whiterockian) gastropods of Nevada; Part 2. Journal of Paleontology 70(1), 56-63.

Rohr, D.M., FIX, M.F. \& Darrough, G. 2004b. Life association of shell and operculum of Ceratopea Ulrich, 1911 (Ordovician, Gastropoda). Journal of Paleontology 78(1), 218-220. DOI 10.1666/0022-3360(2004)078<0218:LAOSAO>2.0.CO;2

Rohr, D.M. \& Measures, E.A. 2001. Middle Ordovician (Whiterockian) gastropods from western Newfoundland. Journal of Paleontology 75(2), 284-294.

DOI 10.1666/0022-3360(2001)075<0284:MOWGOW>2.0.CO;2

Rohr, D.M., Measures, E.A. \& Boyce, W.D. 2004a. Middle Ordovician (Whiterockian) gastropods from the Table Point Formation, western Newfoundland. Newfoundland Department of Mines and Energy Report 04-1, 225-234.

Rohr, D.M., Measures, E.A., Boyce, W.D. \& Knight, I.R. 2000. Ongoing studies of Late Cambrian and Early Ordovician gastropods of western Newfoundland. Current Research 2000, Newfoundland Department of Mines and Energy, Geological Survey, Report 2000-1, 241-250.

Rohr, D.M., Measures, E.A., Boyce, W.D. \& Knight, I. 2001. Early Ordovician gastropods of the Barbace Cove Member (Boat Harbour Formation) and Catoche Formation, western Newfoundland. Newfoundland Department of Mines and Energy, Report 01-1, 113-126.

Rohr, D.M., Measures, E.A., Boyce, W.D. \& Knight, I. 2002. Euomphalopsis and Polhemia (Gastropoda) from the Lower Ordovician Catoche Formation, western Newfoundland. Newfoundland Department of Mines and Energy Report 02-1, 265-275.

Rohr, D.M., Norford, B.S. \& Yochelson, E.L. 1995. Stratigraphically significant Early and Middle Ordovician gastropod occurrences, western and northwestern Canada. Journal of Paleontology 69(6), 1047-1053.

SAlter, J.W. 1859. Figures and descriptions of Canadian organic remains [Ordovician]; Decade I. 47 pp. Geological Survey of Canada, Montreal.

SANDO, W.J. 1957. Beekmantown Group (Lower Ordovician) of Maryland. Geological Society of America Memoir 68, 1-161. DOI 10.1130/mem68-p1

SARDESON, F.W. 1903. Phylogenic stage of the Cambrian Gastropoda. Journal of Geology 11(5), 469-492. DOI $10.1086 / 621092$

SeEly, H. 1910. Preliminary report of the geology of Addison County, Vermont. Report of the State Geologist and Vermont Geological Survey, 257-313. 
SMith, M.P. 1991. Early Ordovician conodonts of East and North Greenland. Meddelelser om Grønland, Geoscience 26, 1-81.

STAUFFER, C.R. 1937. Mollusca from the Shakopee dolomite (Ordovician) at Stillwater. Minnesota. Journal of Paleontology 11(1), 61-68.

Stouge, S. 1984. Conodonts of the Middle Ordovician Table Head Formation, western Newfoundland. Fossils and Strata $16,1-145$.

Stouge, S. 2012. Middle Ordovician (late Dapingian-Darriwilian) conodonts from the Cow Head Group and Lower Head Formation, western Newfoundland, Canada. Canadian Journal of Earth Sciences 49, 59-90.

Stouge, S., Boyce, D.W., Christiansen, J.L., Harper, D.A.T. \& KNIGHT, I. 2002. Lower-Middle Ordovician stratigraphy of North-East Greenland. Geology of Greenland Survey Bulletin 189, 117-125.

Stouge, S., Boyce, W.D., Christiansen, J.L., Harper, D.A.T. \& KNIGHT, I. 2013. Development of the Lower Cambrian-Middle Ordovician Carbonate Platform: North Atlantic Region, 597-626. In Derby, J.R., Fritz, R.D., Longacre, S.A., Morgan, W.A. \& STERnBACH, C.A. (eds) The great American carbonate bank: The geology and economic resources of the Cambrian-Ordovician Sauk megasequence of Laurentia. AAPG Memoir 98.

Swett, K. \& Smit, D.E. 1972. Paleogeography and depositional environments of the Cambro-Ordovician shallow marine facies of the North Atlantic. Geological Society of America Bulletin 83, 3223-3248. DOI 10.1130/0016-7606(1972)83[3223:PADEOT]2.0.CO;2

Tofel, J.E. \& BRETSky, P.W. 1987. Middle Ordovician Lophospira (Archaeogastropoda) from the Upper Mississippi Valley. Journal of Paleontology 61(4), 700-723.

UlRICH, E.O. 1911. Revision of the Paleozoic systems. Geological Society of America Bulletin 22, 247-298. DOI 10.1130/GSAB-22-281

UlRICH, E.O. \& SCOFIELD, W.H. 1897. The Lower Silurian Gastropoda of Minnesota, 813-1081. In ULRICH, E.O., SCOFIELD, W.H., Clarke, J.M. \& Winchell, N.H. The Geological and Natural History Survey of Minnesota, Paleontology 3(2). Harrison and Smith, Minneapolis.

WAGNER, P.J. 2002. Phylogenetic relationships of the earliest anisostrophically coiled gastropods. Smithsonian Contributions to Paleobiology 88, 1-152.
Wenz, W. 1938. Handbuch der Paläozoologie, Bd. 6, Gastropoda. 1639 pp. Gebrüder Bornträger, Berlin.

WHITFIELD, R.P. 1886. Notice of geological investigations along the eastern shore of Lake Champlain, conducted by Prof. H.M. Seely and Prest. Ezra Brainerd, of Middlebury College, with descriptions of the new fossils discovered. Bulletin of the American Museum of Natural History 1, 293-345.

WhitFIELD, R.P. 1890. Observations on the fauna of the rocks at Fort Cassin, Vermont, with descriptions of a few new species. Bulletin of the American Museum of Natural History 3(1), 25-39.

Yochelson, E.L. 1964. The Early Ordovician gastropod Ceratopea from east Greenland. Meddelelser om Grønland 164(7), $1-12$.

Yochelson, E.L. 1973. The Late Early Ordovician Gastropod Ceratopea in the Arbuckle Mountains, Oklahoma. Oklahoma Geology Notes 33(2), 67-78.

Yochelson, E.L. 1975. Early Ordovician gastropod opercula and epicontinental seas. Journal of Research of the U. S. Geological Survey 3, 447-450.

Yochelson, E.L. 1992. The late Early Ordovician gastropod Teiichispira at Port au Port, Newfoundland. Canadian Journal of Earth Sciences 29, 1334-1341. DOI 10.1139/e92-107

Yochelson, E.L. \& BarnetT, S.G. 1972. The Early Ordovician gastropod Ceratopea in the Plattsburgh, New York area. Journal of Paleontology 46(5), 685-687.

Yochelson, E.L. \& BRIDGe, J. 1957 [1958]. The Lower Ordovician gastropod Ceratopea. U. S. Geological Survey, Professional Paper 294H, H281-H304.

Yochelson, E.L. \& Copeland, M.J. 1974. Taphonomy and taxonomy of the Early Ordovician gastropod Ceratopea canadensis (Billings), 1865. Canadian Journal of Earth Sciences 11(1), 189-207. DOI 10.1139/e74-016

Yochelson, E.L. \& PeEl, J.S. 1975. Ceratopea and the correlation of the Wandel Valley Formation, eastern North Greenland. Rapport Grønlands Geologiske Undersogelse [1964] $75,28-31$.

Yochelson, E.L. \& Wise, O.A. 1972. A life association of shell and operculum in the early Ordovician gastropod Ceratopea unguis. Journal of Paleontology 46(5), 681-684.

Yü Wen 1961. Some Lower Ordovician gastropods from Zhuozishan District, Inner Mongolia. Acta Palaeontological Sinica 9, 24-37. 